teorema

Vol. XXXVI/1, 2017, pp. 57-82

ISSN: 0210-1602

[BIBLID 0210-1602 (2017) 36:1; pp. 57-82]

\title{
Was Wittgenstein a Liberal Philosopher?
}

\author{
Robert Vinten
}

RESUMEN

La pregunta si Wittgenstein fue un filósofo liberal ha recibido menos atención que la de si fue un filósofo conservador, pero, como Robert Greenleaf Brice ha defendido recientemente, hay muchos indicios de liberalismo en algunas de sus observaciones, y algunos filósofos, como Richard Eldridge, han sostenido que hay un cierto tipo de liberalismo que se sigue de la filosofía de su última etapa. Richard Rorty ha sacado también conclusiones liberales a partir de la perspectiva filosófica que se basa en la obra de Wittgenstein y Alice Crary ha sugerido que las lecciones aprendidas de su propia interpretación de Wittgenstein se "reflejan en formas de vida social que incorporan los ideales de la democracia liberal". En este artículo, voy a defender tanto que Wittgenstein no era un liberal como que su filosofía no implica una perspectiva liberal. Los autores de que se discuten aquí no prueban que de las observaciones filosóficas de Wittgenstein se desprendan amplias conclusiones ideológicas de ningún tipo.

Palabras Clave: Wittgenstein, liberalismo, democracia liberal, Brice, Eldridge, Rorty, Crary.

ABSTRACT

The question of whether Wittgenstein was a liberal philosopher has received less attention than the question of whether he was a conservative philosopher but, as Robert Greenleaf Brice has recently argued, there are hints of liberalism in some of his remarks, and some philosophers, like Richard Eldridge, have argued that a kind of liberalism follows from Wittgenstein's later philosophy. Richard Rorty has also drawn liberal conclusions from a philosophical viewpoint which draws on Wittgenstein's work and Alice Crary has suggested that the lessons learned from her own interpretation of Wittgenstein are "reflected in forms of social life that embody the ideals of liberal democracy". Here I will argue both that Wittgenstein was not a liberal and that his philosophy does not imply a liberal viewpoint. The authors discussed here do not demonstrate that any broad ideological conclusions follow from Wittgenstein's philosophical remarks.

KEYwords: Wittgenstein, Liberalism, Liberal Democracy, Brice, Eldridge, Rorty, Crary.

\section{INTRODUCTION}

There is a substantial literature on the question of whether Wittgenstein was a conservative philosopher ${ }^{1}$ but much less has been written on 
the question of whether Wittgenstein was a liberal philosopher despite the fact that, as Robert Greenleaf Brice has recently argued [Brice (2014), pp. 86-94], there are hints of liberalism in Wittgenstein's writings. ${ }^{2}$ Brice ultimately argues that the case for Wittgenstein being a liberal is no stronger than the case for him being a conservative. In both cases the evidence is a long way from conclusive. However, other philosophers have been less circumspect. In his essay 'Wittgenstein and the Conversation of Justice', Richard Eldridge argues that "...a kind of substantive or weak perfectionist liberalism" follows from "...the condition of the human person that is enacted in Philosophical Investigations" [Eldridge (2003), pp. 127128]. Richard Rorty puts a pragmatist spin on Wittgenstein's work and suggests that liberalism is a mode of thought with greater utility than others; one which allows us to cope better. And Alice Crary, while critical of Rorty, suggests that the lessons learned from her own interpretation of Wittgenstein are "reflected in forms of social life that embody the ideals of liberal democracy" [Crary (2000), p. 141]. ${ }^{3}$

In this paper I will agree with Brice that there is not a particularly strong case in favour of Wittgenstein being a liberal and nor is there a particularly strong case to be made in favour of liberalism using Wittgenstein's philosophical writings. In the course of coming to those conclusions I will first examine the variety of positions going by the name of liberalism. I will then go on to look at the case that Brice pieces together in support of the claim that Wittgenstein was a liberal in Exploring Certainty. Following that, I will go on to argue that Eldridge, Rorty, and Crary fail to demonstrate that there are liberal tendencies in Wittgensteinian philosophy. While agreeing with much of what Crary says in her arguments against Rorty I will argue that no broad ideological conclusions follow from Wittgenstein's philosophical remarks. ${ }^{4}$

\section{LIBERALISM}

The most obvious thing to say about liberalism is that liberals seek after liberty or freedom. However, there are different accounts of what liberty and freedom amount to and of what it is that should be free. Some philosophers stress negative freedom, i.e. freedom from coercion by others; ${ }^{5}$ while other philosophers stress positive freedom, arguing that someone is free only if they are autonomous or selfdirected $^{6}$ or that someone is free only if they have effective power to act. ${ }^{7}$ Some liberals emphasize the freedom of people to do what they 
like as long as their exercise of their freedom does not interfere with other people's whereas others emphasize free markets.

Liberals nowadays often tie their support for freedom to support for democracy but there is no necessary connection between liberalism and support for democracy. ${ }^{8}$ In their entry on liberalism in the Stanford Encyclopedia of Philosophy Gerald Gaus, Shane D. Courtland, and David Schmidtz suggest that Thomas Hobbes could be considered a liberal because he adheres to the 'fundamental liberal principle', namely the claim that "restrictions on liberty must be justified", 9 despite the fact that Hobbes does then go on to argue that severe restrictions on liberty can be justified. Hobbes was not a supporter of democracy and it is also questionable whether one of the founding fathers of liberalism, John Locke, was. Locke is rightly credited with inspiring moves towards greater democracy and toleration but he was not in favour of women having the vote or of a universal male franchise [Thomas (1995), p. 41]. Locke argued in favour of religious toleration but did not think that such toleration should extend to atheists or to Catholics. ${ }^{10}$ And it is not just liberals from centuries ago that have been ambivalent about democracy; Friedrich Hayek, in an interview with the Chilean newspaper El Mercurio said that he preferred ".... liberal dictator to democratic government lacking liberalism". The key ingredient of a liberal society, according to Hayek, was free markets. Dictatorship was not his professed ideal but was preferable, in his view, to a democratically elected government that placed severe impediments ('impurities') in the way of free markets, such as democratic trade unions and government controlled industry. His ideal was a democracy "clean of impurities". In his ideal world it seems that he would have liked to avoid having an electorate able to vote for government control of industry or able to organize themselves into unions. In the interview with El Mercurio mentioned above Hayek defended the military dictatorship of General Pinochet in Chile, ${ }^{11}$ which had overthrown a democratically elected socialist government and had rounded up thousands of opponents and had them killed. Classical liberals such as Hayek and 'neoliberals' like Margaret Thatcher and Ronald Reagan were of the opinion that Pinochet's dictatorship was better than democratically elected socialists. ${ }^{12}$

However, not all liberals are in the classical mold of Locke and Hayek. Modern liberals in the tradition of J. S. Mill, L. T. Hobhouse, and John Rawls tend to emphasize the ability of individuals to develop themselves in "manifold diversity" [Mill (1869), III. 2] and this al- 
so means that they tend towards supporting toleration of other people and their (diverse) opinions. The liberal positions that are most relevant here are those described by Brice, Eldridge, Rorty, and Crary, and in each of these cases it would be fair to say that they are modern liberals or that the liberalism they focus their attention on is of the modern variety.

\section{1. Brice on Liberalism}

According to Brice, important elements of liberalism include, "a respect for... a reasonable pluralism" 13 of beliefs and opinions, and with that a recognition of the capacity of human beings for tolerance and acceptance of others who disagree with oneself. Brice lists further features that he deems essential to liberalism including “.... concern for, and a respect of the working class; a concern for and a respect of the environment; an abhorrence of war, and a willingness to share what one has with others" [Brice (2014), p. 90]. On Brice's account John Stuart Mill is a paradigmatic liberal and Rawls is cited in listing the key elements of liberalism. Brice also, rather eccentrically, describes Marx as a liberal thinker [Brice (2014), p. 90], although Marx would more usually be thought of as an opponent of the liberal thought that grew up with capitalism. This suggests that Brice has left-wing ideology more generally in mind rather than just left-wing varieties of liberalism.

The description of liberalism given by Brice stands in stark contrast to the kind of views held by classical liberals like Hayek, which suggests that, as Alan Ryan says "...we should be seeking to understand liberalisms rather than liberalism" [Ryan (1993), p. 292].

\section{2. Eldridge on Liberalism}

Like many liberals, Richard Eldridge places emphasis on the notion of freedom. In particular, Eldridge repeatedly emphasizes the notion of 'expressive freedom' and suggests that achieving expressive freedom is Wittgenstein's primary aim. So, for example, he says that the Philosophical Investigations is "a drama of a continuing struggle to achieve expressive freedom" [Eldridge (1997), p. 92] and that "[t]here is in Pbilosophical Investigations a continuing tragic not-reaching of a goal, and nonetheless a continuing aspiration to achieve expressive freedom..." [Eldridge (1997), p. 94]. Eldridge hints at what he means by this by presenting examples of "sureness in self presentation" including "the power and restraint of Gil Shaham's performances of the Prokofiev violin concertos" [Eldridge (1997), pp. 6-7]. So, the Philosophical Investigations, according to Eldridge, “...presents a 
protagonist seeking to articulate the terms for full human self-command and self-expression" [Eldridge (1997), p. 7].

Eldridge spells out what the liberalism that he finds in Wittgenstein would involve in his 'Wittgenstein and the Conversation of Justice' [Eldridge (2003), pp. 117-128]. There he says that since there are various, reasonably competing, ways of life we should be tolerant of others and mutually respectful. The framework of this variety of liberalism would also involve a commitment to personal autonomy as a substantive good. This, presumably, chimes with the goal of "full human self-command and self-expression" mentioned above.

\section{3. Rorty's Utopian Liberalism}

Richard Rorty's liberalism is a curious mixture of the kind of politics associated with the left and the politics of the right. On the one hand he stresses the notion of solidarity (which he opposes to that of 'objectivity'), supports trade unions in their demands for better wages and conditions, ${ }^{14}$ applauds the development of substantial welfare states, ${ }^{15}$ and opposes the growth of economic inequality [Rorty (1999), p. 243] as well as inequality of opportunity [Rorty (1999), p. 231]; but on the other hand he sees a lack of patriotism as a problem with the left [Rorty (1999), p. 252], opposes multiculturalism [Rorty (1999), pp. 252-253], and sees free markets as indispensable [Rorty (1999), p. 204]. ${ }^{16}$ However, despite the fact that his politics contains right-wing elements Rorty's liberalism is closer to the modern liberalism described by Brice - influenced by Mill and Rawls - than it is to the classical liberalism of Locke and Hayek. Rorty himself recognizes something of a split in his politics and that is reflected in the fact that he calls himself a 'liberal ironist'.

Rorty's discussion of liberalism tends to be an abstract one - presenting an ideal rather than describing the way that liberals actually behave. He talks about what 'liberal democracies' do or don't do but not about what, for example, the U. S. government does. So he says that "[a] liberal democracy... will use force against the individual conscience just in so far as conscience leads individuals to act so as to threaten democratic institutions" [Rorty (1990), p. 285] but modern liberal democracies, such as the United States, use force in so many instances that conflict with this that it is highly doubtful whether they even aim at acting on that principle much of the time. Rorty acknowledges that his liberalism is utopian (and his indebtedness to Mill) when he says, that the institutions in the society he envisages, 
would be regulated by John Stuart Mill's dictum that everybody gets to do what they like as long as it doesn't interfere with other people's doing the same.

As far as I can see, nothing theoretical that we have learned since Mill's time... give[s] us reason to revise as opposed to supplement our previous descriptions of utopia. [Rorty (1999), p. 235].

A final aspect of Rorty's liberalism worth noting here is that he sees himself as following in the footsteps of American pragmatists and as being influenced by pragmatist elements in Wittgenstein's thought, as he sees it. This means that he thinks about philosophical and political views in terms of their utility or their inutility, ${ }^{17}$ their usefulness, or their point. When thinking about language he wants to focus on words as tools for coping with our environment rather than thinking about language as being representational..$^{18} \mathrm{He}$ contrasts his own view, with its stress on solidarity, with the realist view which stresses objectivity and emphasizes notions like truth and representation. One way of advancing towards the liberal utopia that he envisages is to develop a new vocabulary that draws people into recognizing the relative utility of liberalism compared to other ways of thinking. ${ }^{19}$ On Rorty's view there is no clear distinction to be made between philosophy and other disciplines: “...both scientists and philosophers help us learn to get around the world better. They do not employ distinct methods" [Rorty (2007), p. 166].

Wittgenstein's influence can be seen in Rorty's talk of words as tools. At the beginning of the Philosophical Investigations Wittgenstein contrasts the 'Augustinian view', according to which words name objects and sentences combine names $(\$ 1)$, with the view of words as tools. He suggests that we " $[t]$ hink of the tools in a toolbox: there is a hammer, pliers, a saw, a screwdriver, a rule, a glue pot, glue, nails, and screws. - The functions of words are as diverse as the functions of these objects" [Wittgenstein (2009), \$11].20 Rorty also suggests that the Wittgensteinian maxim "Don't look for the meaning, look for the use" suggests a pragmatic reading of his work. It suggests to Rorty that "any utterance can be given significance by being batted around long enough in more or less predictable ways" [Rorty (2007), p. 172], and so leads to Rorty's view that we can formulate more fruitful ways of talking, such as using a 'vocabulary' employing the term 'solidarity' rather than that of 'objectivity'. We can talk in ways that allow us to cope better and a kind of liberal ironist vocabulary would allow us to do that, according to Rorty. ${ }^{21}$ One other way in which Wittgenstein has influenced Rorty is in his talk of 
'language games'. Rorty seems to see his talk of vocabularies as being similar to Wittgenstein's talk of language games and forms of life. ${ }^{22}$

\section{4. Crary and Liberalism}

Alice Crary, in her article 'Wittgenstein's Philosophy in Relation to Political Thought', suggests that the lesson we learn from Wittgenstein about "investigating established modes of thought and speech [is]...one [she suspects] we would find reflected in forms of social life that embody the ideals of liberal democracy" [Crary (2000), p. 141]. What is meant by 'liberal democracy' is not perfectly clear but this term is typically used to distinguish modern, capitalist, representative democracies with elections, human rights, and civil liberties, from both other kinds of democracies (e.g. direct democracies such as in the Paris Commune) and from undemocratic states with limited freedoms (e.g. Saudi Arabia). According to this rough outline, countries as different as the United States, Japan, and Sweden would all count as liberal democracies. A state might count as a liberal democracy whether it has a social democratic government or a conservative one and so to say that the lesson we learn from Wittgenstein is reflected in forms of social life embodying the ideals of liberal democracy is not to say that Wittgenstein was a liberal or that his philosophy has liberal implications, and so her claim is weaker than the one made by Eldridge. In 'Wittgenstein's Pragmatic Strain' Crary suggests that lessons from Wittgenstein might help to resolve disputes between liberals and communitarians and so the suggestion is that her own position combines elements of the two approaches [Crary (2003), pp. 369-390].

Crary acknowledges that she does not build a conclusive case for this conclusion but that is not her intention in the article. Her intention is to demonstrate that widely accepted interpretations of Wittgenstein's philosophy, from both left and right, misunderstand Wittgenstein's account of meaning and so their conclusions about the political implications of Wittgenstein's philosophy are shaky. So, Crary makes something of a negative case for her position by undermining the arguments of people like Ernest Gellner and J. C. Nyiri, who argue that Wittgenstein's philosophy has conservative implications because it does not allow for rational criticism of other forms of life.

\section{5. Summary}

The philosophers under consideration here have a conception of liberalism that is a modern one. What this means is that they emphasize the kind of freedom, democracy, toleration, and mutual respect between 
people with differing moral and political outlooks that is found in modern capitalist representative democracies and that they seek to broaden the scope of those values within a liberal-democratic framework. However, there are other kinds of liberals: classical liberals and neoliberals, whose emphases are different. In the next section I will consider whether Wittgenstein might be considered a liberal of some sort, whether liberal democracies are particularly conducive to carrying out the kind of philosophical work that Wittgenstein engaged in, and whether Wittgenstein's philosophy might be of help in promoting liberal values.

\section{WITTGENSTEIN AND LIBERALISM}

\section{1. Brice's Case for Wittgenstein Being a Liberal}

In Exploring Certainty Robert Greenleaf Brice tries to demonstrate that something of a case can be made in favour of Wittgenstein being a liberal just as some kind of case can be made in favour of saying that Wittgenstein was conservative. However, he is clear that he does not wish to endorse the view that Wittgenstein was a liberal. His point is to argue that "it is wrong to try to draw any definitive conclusions from the "evidence"' [Brice (2014), p. 86], given that both kinds of cases can be made with some force.

Brice starts by examining evidence of Wittgenstein's political views. He cites a passage from Ray Monk's biography of Wittgenstein in which Monk says that, "[t]here is no doubt that during the political upheavals of the mid-1930s Wittgenstein's sympathies were with the working class and the unemployed, and that his allegiance, broadly speaking, was with the Left" [Monk (1991), p. 343]. Monk himself cites evidence from friends of Wittgenstein in support of his claim, including George Thomson's claims that Wittgenstein "supported [Marxism] in practice" and that Wittgenstein, in the 1930s, was "alive to the evils of unemployment and fascism and the growing danger of war" [Thomson (1979), pp. 86-88]. As noted in section II. 1. above, Brice thinks that "...a concern for, and a respect of the working class" is essential to liberalism, and so Wittgenstein's sympathy for the working class counts as evidence in favour of him being a liberal, according to Brice.

However, it is debatable whether sympathy for the working class is essential to liberalism. There are liberals, like Hayek, who are content to see trade union rights removed, since these are a barrier to the free markets that he particularly treasures, and it seems that somebody with a par- 
ticular sympathy for the working class would not be so blasé about removing a worker's right to organize in trade unions. Ideologies particularly associated with sympathy for the working class are socialist and communist ideologies and so the passages Brice relies on (from Monk's biography of Wittgenstein) would perhaps be better used in support of claiming that Wittgenstein was a socialist or communist rather than to support the claim that he was a liberal. Brice's definition of liberalism is extremely broad - too broad, in that it encompasses Marxist views - but this does not undermine his central claim, that "it is wrong to try to draw any definitive conclusions from the "evidence" about Wittgenstein's views. The fact that there is some evidence of Wittgenstein holding leftwing views undermines the claims made by Nyiri and Bloor about Wittgenstein's supposed conservatism and this supports Brice's conclusion.

Brice also cites passages which suggest that Wittgenstein was opposed to bourgeois thinking, ${ }^{23}$ that he was a pacifist (or at least abhorred war), ${ }^{24}$ and that he supported the Labour Party in the 1945 elections. However, just as in the case of sympathy for the working class, these stances are not associated particularly with liberalism. The Labour Party in Britain is a social democratic, reformist socialist party, not a liberal one and the people voting for it are in any case not necessarily entirely in agreement with its views. Opposition to bourgeois thinking is more often associated with Marxism, socialism, and anarchism than with liberalism. In fact, liberalism, as an ideology which defends capitalism, could well be seen as a form of bourgeois ideology itself. Pacifism, again, is not particularly associated with liberals. There are anarchists who are pacifists, socialists who are pacifists and liberals who are pacifists. Moreover, it is clear that Wittgenstein was not a lifelong pacifist, despite sometimes saying things which indicated that he inclined in that direction. For one thing, he was eager to fight in the First World War, and did so as a volunteer, from the beginning of the war in 1914 and after the Second World War Wittgenstein wrote that:

The hysterical fear over the atom bomb now being experienced, or at any rate expressed, by the public almost suggests that at last something really salutary has been invented. The fright at least gives the impression of a really effective medicine. I can't help thinking: if this didn't have something good about it the philistines wouldn't be making an outcry... the bomb offers a prospect of the end, the destruction, of an evil, - our disgusting soapy water science. And certainly that's not an unpleasant thought [Wittgenstein (1980), p. 49]. 
So the passages that Brice cites do not lend credibility to the conclusion that Wittgenstein was a liberal.

Brice also suggests that support for the thesis that Wittgenstein was a liberal can be found in Wittgenstein's more philosophical writings. He cites Wittgenstein's 'Remarks on Frazer's Golden Bough' in attributing to Wittgenstein the traditional liberal value of tolerance. However, the passage that Brice cites from Wittgenstein makes no mention of tolerance of other's beliefs or of acceptance of people with different beliefs. The point that Wittgenstein makes is better described as being about methodology in anthropology and about the correct categories for describing the beliefs of others. In the passage that Brice cites Wittgenstein says:

Frazer's account of the magical and religious views of mankind is unsatisfactory; it makes these views look like errors... The very idea of wanting to explain a practice seems wrong to me. All that Fraser does is make them plausible to people who think as he does. It is very remarkable that in the final analysis all these practices are presented as, so to speak, pieces of stupidity. But it will never be plausible to say that mankind does all that out of sheer stupidity [Wittgenstein (1993), p. 119].

Wittgenstein is suggesting that Frazer is limited in his explanatory framework given that he thinks of magic as a kind of proto-science. We do not have to conceive of magic in this way, Wittgenstein points out. Symbolic and ritualistic behavior need not involve false beliefs about its instrumental efficacy. Belief in such things as killing a priest in his prime in order to keep his soul fresh (the kind of beliefs that Frazer sought to explain) are not empirical beliefs. As Peter Hacker points out, "[t]hey are not based on observations of constant conjunctions in nature, and cannot be shown to be mistaken by an experimentum crucis or more careful inductive procedures" [Hacker (2001), p. 82]. In the kinds of cases under consideration by Frazer, Wittgenstein wants to say that "there is no question of an error". ${ }^{25}$ Similar considerations apply to the other passages from Wittgenstein cited by Brice [Wittgenstein (1993), p. 125 and p. 131], i.e. no mention is made of toleration or acceptance of the beliefs discussed by Frazer; rather points are made about methodology, explanation and understanding in anthropology.

Brice also suggests that liberal conclusions about acceptance flow from Wittgenstein's remarks in On Certainty about forms of life shifting or changing ${ }^{26}$ and he cites Wittgenstein's Remarks on the Pbilosophy of Psychology (Vol. II) in connection with the theme of acceptance: "Given the 
same evidence, one person can be completely convinced and another not be. We don't on account of this exclude either one from society, as being unaccountable and incapable of judgement" (\$685). However, in none of these instances does Wittgenstein himself draw any conclusions about tolerance or acceptance and nor do such conclusions follow from what he says. It is interesting, for one thing, that in the remark immediately following the one cited by Brice (from RPP, Vol II, above) Wittgenstein says “But mightn’t a society do precisely this?" (\$686) with no comment on whether excluding people in such a way would be desirable or not, suggesting that the point he is making is not about tolerance of others but rather one about how we think about judgement.

So, although Brice succeeds in demonstrating, pace Nyiri and Bloor, that Wittgenstein's was far from a thoroughgoing conservative, he does not produce a convincing case in favour of Wittgenstein being a liberal. ${ }^{27}$

\section{3. Eldridge, Liberalism, and Wittgenstein}

Recall that Eldridge places particular emphasis on the notion of 'expressive freedom' in his account of Wittgenstein's Philosophical Investigations. The path carved out by the discussion between the various voices of the Philosophical Investigations is a "drama of a continuing struggle to achieve expressive freedom" [Eldridge (1997), p. 92]. Elsewhere Eldridge describes the Investigations as "the ongoing reenactment of a condition [the condition of the human subject] - rather than... the conclusive establishment via argument (deductive or quasi-deductive) argumentation of theses about the nature of meaning or understanding" [Eldridge (2003), p. 235, fn.10] and Eldridge goes on to argue that, "[w] hat follows... from the condition of the human person that is enacted in Philosophical Investigations is... a kind of substantive or weak perfectionist liberalism" [Eldridge (2003), p. 127]. It is a form of perfectionist liberalism, on Eldridge's view, in part because it aims to "articulate the terms of full human selfcommand and self-expression"28 [Eldridge (1997), p. 7]. The upshot of all of this is a liberalism involving tolerance, mutual respect, and a commitment to autonomy.

The first thing that might make us slightly wary of Eldridge's account is that the elements Eldridge takes to be central do not appear in the Pbilosophical Investigations at all; at least not in the form that Eldridge discusses them. Not only does Wittgenstein not use the term 'expressive freedom' but the central liberal notion of freedom or liberty is not mentioned in the Philosophical Investigations at all. There is also no mention of autonomy, tolerance, or mutual respect. The expression 'self-command' 
is not used, although early on in the Investigations Wittgenstein does talk of commanding "a clear view of the aim and functioning of the words [in a language game]" [Wittgenstein (2009), \$5] and later, again, tells us that commanding "a clear view of the use of our words" [Wittgenstein (2009), \$122] is one of his principal aims.

So, is there any truth in Eldridge's account? - Certainly it is true that Wittgenstein does not aim at debating or putting forward theses. ${ }^{29}$ In discussing the nature of philosophy, as he practices it, Wittgenstein says that, "[i]f someone were to advance theses in philosophy, it would never be possible to debate them because everyone would agree to them" [Wittgenstein (2009), \$128]. It is also true that Wittgenstein does sometimes speak of an element of self-control being involved in philosophizing. Eldridge cites a passage from the 'Big Typescript' in support of his case, where Wittgenstein says:

DiFFICULTY OF PHILOSOPHY NOT THE INTELLECTUAL DIFFICULTY OF THE SCIENCES, BUT THE DIFFICULTY OF A CHANGE OF ATTITUDE. RESISTANCE OF THE WILL MUST BE OVERCOME... Work on philosophy is... actually more of //a kind of// work on oneself. On one's own conception. On the way one sees things... THE METHOD OF PHILOSOPHY: THE PERSPICUOUS REPRESENTATION OF GRAMMATICAL //LINGUISTIC// FACTS. THE GOAL: THE TRANSPARENCY OF ARGUMENTS... ${ }^{30}$

Eldridge also cites a passage from Culture and Value, where Wittgenstein says that, "[t]he edifice of your pride has to be dismantled. And that is terribly hard work" [Wittgenstein (1980), p. 26e]. ${ }^{31}$ Another respect in which Eldridge's account is at least partially correct is that he claims that Wittgenstein wants to avoid being dogmatic or doctrinaire. So Eldridge says of Wittgenstein that he wants to "...avoid all at once dogmatism, nihilist skepticism, and simple indifferentism..." [Eldridge (1997), p. 7] and that "onwardness and self-revision, not doctrine and self-completion are pervasive" [Eldridge (1997), p. 89]. There is support for this in Wittgenstein's later work, for example in the Philosophical Investigations, where Wittgenstein raises worries about, "[t]he dogmatism into which we fall so easily in doing philosophy" [Wittgenstein (2009), \$131]. Wittgenstein makes it clear that he is far from seeking to impose a set of beliefs or opinions (i.e. being doctrinaire), in his lectures (1939) where he said that he was not advancing opinions at all [Wittgenstein (1976), p. 103] and said that if anyone were to dispute anything he said he would let that point drop and move on to something else [Wittgenstein (1976), p. 22]. 
Nonetheless, there are problems with Eldridge's account of Wittgenstein. Whereas Eldridge contrasts Wittgenstein's opposition to advancing theses in philosophy with "the ongoing reenactment of a condition", Wittgenstein himself, in the passages on philosophy in the Philosophical Investigations, contrasts advancing theses with presenting descriptions of the grammar of our language with the goal of dissolving philosophical problems. So, in the Investigations Wittgenstein says that,

...we may not advance any kind of theory. There must not be anything hypothetical in our considerations. All explanation must disappear, and description alone must take its place. And this description gets its light - that is to say, its purpose - from the philosophical problems. These are, of course, not empirical problems; but are solved through an insight into the workings of our language... The problems are solved... by assembling what we have long been familiar with [Wittgenstein (2009), \$109].

The purpose of philosophy, as Wittgenstein does it, is not self-command (although an element of self-command is involved in fulfilling this purpose) but to dissolve philosophical problems by assembling relevant grammatical rules that we are already familiar with - by 'assembling reminders' of the correct use of words ("the work of a philosopher consists in marshalling recollections", [Wittgenstein (2009), \$127]). The element of self-command that is involved - the overcoming of the resistance of the will, or the dismantling of pride - is required because we are 'bewitched' by sentences that appear to make sense but which do not: "Philosophy is a struggle against the bewitchment of our understanding by the resources of our language" [Wittgenstein (2009), \$109]. Similarly, it is not "onwardness and self-revision", as Eldridge says, that Wittgenstein opposes to dogmatism and doctrine, rather it is the careful examination of the grammar of our language. So, for example, when we are faced with a philosophical problem in mathematics what we should do is to "... render surveyable the state of mathematics that troubles us" [Wittgenstein (2009), \$125]. In order to achieve understanding in philosophy we should produce surveyable representations of the relevant region of grammar [Wittgenstein (2009) \$122] (i.e. remind ourselves of how the relevant words are ordinarily used).

When Wittgenstein talks about dogmatism in philosophy he does not have in mind the kind of objectionable blinkered or inflexible stances taken in politics that might be contrasted with more open-minded or perhaps liberal stances, rather he is talking about a kind of philosophy in which an 
archetype or a model is held onto in such a way that it amounts to a "preconception to which reality must correspond". ${ }^{2}$ His targets were Spengler, who he accused of "dogmatically attribut[ing] to the object what should be ascribed only to the archetype" [Wittgenstein (2009), \$131] and his own earlier philosophy. As Peter Hacker puts it, “...it is characteristic of misguided [dogmatic] philosophy to insist that things must be thus-and-so, because this is how one has resolved to represent them" [Hacker (2013), p. 167]. Wittgenstein's point is that grammatical rules do not describe de re necessities, rather they are rules for the use of words (i.e. not descriptions at all). Wittgenstein's philosophy is not doctrinaire or opinionated because it does not involve presenting opinions at all. The activity that Wittgenstein is engaged in is the description of norms of representation, the description of grammar, with the purpose of getting rid of philosophical (i.e. conceptual) confusion and this is quite different to presenting opinions (i.e. not grammatical claims) on matters in politics, morality, or metaphysics. Describing grammar is also a quite different kind of activity to theorizing, which aims at explaining some phenomenon.

Eldridge himself acknowledges the appeal of this account of Wittgenstein's philosophy, attributing the view to Gordon Baker and Peter Hacker. He says that it is "...a considerable and powerful view. Put into practice, it yields trenchant criticisms of a great deal of work in linguistics, cognitive psychology, and the theory of perception..." [Eldridge (1997), p. 103]. However, Eldridge thinks that this account is open to serious objections. On the one hand it acknowledges Wittgenstein's remark about philosophy not advancing theses or any kind of theory, but on the other it attributes a thesis to Wittgenstein, namely that grammar is autonomous.

However, it is not clear that Eldridge's objection finds its target. For one thing, Baker and Hacker themselves do not refer to 'grammar is autonomous' as a thesis. So, there is no explicit commitment from them to the clash that Eldridge identifies. Moreover, it is not clear that 'grammar is autonomous' is a thesis. If it were a thesis then it is, at best, unclear what evidence could be adduced in support of it. An alternative way of viewing the remark that 'grammar is autonomous' is to view it as itself a kind of grammatical remark (and so not the kind of thing such that we might adduce evidence in support of it). The remark basically amounts to saying that " $[\mathrm{t}]$ here is no such thing as justifying grammar as correct by reference to reality" [Baker and Hacker (2009), p. 336], and so it rules out philosophical attempts to do that, such as that in Wittgenstein's own earlier work. 'Grammar is autonomous' could be taken to be like 'inner states stand in need of outward criteria', in playing the role of a synoptic description 
"drawing together and interrelating a multitude of grammatical propositions that are truisms" [Baker and Hacker (2009), p. 20].

The other problem facing Eldridge's objection is that it seems as though if he objects to Baker and Hacker on those grounds he would also have to bring the objection against Wittgenstein himself, since Wittgenstein makes remarks in several places that amount to saying that grammar is autonomous. For example, in Philosophical Grammar Wittgenstein says that " $[\mathrm{g}] \mathrm{rammar}$ is not accountable to any reality. It is grammatical rules that determine meaning (constitute it) and so they themselves are not answerable to any meaning" [Wittgenstein (1974), 184], and in Zettel we find Wittgenstein saying that, "one is tempted to justify rules of grammar by statements like 'But there really are four primary colours'. And the remark that the rules of grammar are arbitrary is directed against the possibility of this justification [Wittgenstein” (1967), \$331]. It seems unlikely that Wittgenstein himself would have held both that 'grammar is autonomous' is a thesis and that he would remark that there are no theses in philosophy. This lends support to the view that 'grammar is autonomous' is not a thesis at all.

Given the problems with Eldridge's account (i.e. the inconsistencies of his account with Wittgenstein's own professed aims) and the plausibility of Baker and Hacker's account, I suggest that the latter is preferable, and so the case that Eldridge makes for there being a variety of perfectionist liberalism in Wittgenstein's work is seriously undermined. ${ }^{33}$ Neither Brice, nor Eldridge has made a convincing argument in favour of Wittgenstein being a liberal. In the next section I will turn to Rorty's pragmatic case for liberalism and argue that it does not suggest that there is any kind of liberalism in Wittgenstein's philosophical work.

\section{4. Rorty, Wittgenstein, and Liberalism. Rorty's Wittgenstein}

In the section above (II. 3.) it was suggested that there were some commonalities between Wittgenstein's and Rorty's philosophies. However, with regard to the topic in question, namely Rorty's pragmatic case for liberal ironism, it is the differences between the two that are more striking. (i) One way in which Rorty and Wittgenstein differ is in how they conceive their relationship to traditional philosophy. Rorty's pragmatist line is that "[c]riticisms of other philosophers' distinctions and problematics should charge relative inutility rather than 'meaninglessness' or 'illusion' or 'incoherence"' [Rorty (1998), p. 45], whereas, as Alice Crary notes, "it is a signature gesture of Wittgenstein's philosophy... to appeal to nonsense as a term of philosophical criticism" [Crary (2000), p. 128] and Crary's take on Wittgenstein is 
supported by remarks that Wittgenstein himself made, such as his remark that " $[t]$ he results of philosophy are the discovery of some piece of plain nonsense..." [Wittgenstein (2009), \$119]. ${ }^{34}$ (ii) Wittgenstein does not think of his work in philosophy as consisting in creating new vocabularies as Rorty does. Rorty thinks that we should give up on certain distinctions and ways of speaking associated with past philosophy and promote new, more useful, ways of speaking (such as the liberal ironist vocabulary that he wants to promote). So, for example, he suggests that we set aside "the subjectobject, scheme-content, and reality-appearance distinctions and [think]... of our relation to the rest of the universe in purely causal, as opposed to representationalist, terms" [Rorty (1998), p. 49], that "we cannot employ the Kantian distinction between morality and prudence" [Rorty (1999), p. xvi], and that we should "stop using the distinctions between finding and making, discovery and invention, objective and subjective" [Rorty (1999), p. xviii]. Wittgenstein also has problems with distinctions made by traditional philosophers but he does not suggest jettisoning the old dichotomies. Instead he says that "[w] hat we do is to bring words back from their metaphysical to their everyday use" [Wittgenstein (2009), \$116]. What that means is that we should 'marshall recollections' or 'assemble reminders' [Wittgenstein (2009), \$127] of the ordinary use of the words in question so that we can recognize that the way that past philosophers have used the words in question is nonsensical - "to pass from unobvious nonsense to obvious nonsense" [Wittgenstein (2009), \464]. (iii) The difference in philosophical approaches is summed up by one of James Conant's objections to Rorty. Wittgenstein famously said that his aim in philosophy was " $[\mathrm{t}] \mathrm{O}$ show the fly the way out of the fly-bottle" [Wittgenstein (2009), \$309] and I take it that this aim was synonymous with the aim mentioned above, of passing from unobvious to obvious nonsense - to make clear where past philosophers were confused and to remind people of how the relevant words are used ordinarily. However, James Conant notes that "Rorty's recommendation appears to be that one should leave the fly in the flybottle and get on with something more interesting" [Conant (1990), p. iii] and Rorty himself, in commenting on this assessment, says that "Conant here gets me exactly right" [Rorty (1998), p.47, fn.17]. (iv) It follows from Wittgenstein's account of philosophy as involving uncovering or discovering nonsense that he would not want to affirm the negation of the traditional philosophical 'theories' that he examines, because the negation of nonsense is itself nonsense. However, as Alice Crary [Crary (2000), pp. 127-128] and Hilary Putnam have observed, Rorty seems to want to do something like affirming the negation of traditional philosophical posi- 
tions. Rorty objects to realism but responds to it by saying that we can't describe reality in itself [Putnam (1990), p. 39]. ${ }^{35}$ Whether or not Rorty's position is coherent, it clearly is not Wittgenstein's. ${ }^{36}(\mathrm{v})$ Rorty and Wittgenstein also differ in their approach to the issue of how philosophy relates to science. Throughout his career Wittgenstein made a clear distinction between philosophy and science. In the Tractatus Logico-Pbilosophicus Wittgenstein said unequivocally that "philosophy is not one of the natural sciences" [Wittgenstein (1961), 4.111] and in the Philosophical Investigations he says that "...our considerations [in philosophy] must not be scientific ones" [Wittgenstein (2009), \$109]. Philosophy, unlike science, describes linguistic norms [Wittgenstein (2009), \$124] with the aim of dissolving (conceptual) confusion, according to Wittgenstein. However, Rorty, says that "...both scientists and philosophers help us to learn to get around the world better. They do not employ distinct methods" [Rorty (2007), p. 166]. (vi) A final difference between Rorty and Wittgenstein that is particularly worth commenting on here is their difference over the issue of meaning and use. Rorty presents us with the outline of a "'social practice' theory of language" [Rorty (2007), pp. 172-173] which he describes as a pragmatic theory "epitomized in the Wittgensteinian maxim 'Don't look for the meaning, look for the use"' [Rorty (2007), p. 172]. However, according to Wittgenstein's conception of philosophy there could be no theses in philosophy and although Wittgenstein is credited with this 'maxim' he never himself said such a thing. Wittgenstein did not recommend replacing talk of meaning with talk of use and he did not think that meaning could be explicated in terms of use in every instance. What Wittgenstein actually said in the Philosophical Investigations was that "[f]or a large class of cases of the employment of the word 'meaning' - though not for all - this word can be explained in this way: the meaning of a word is its use in the language..." [Wittgenstein (2009), §43]. Rorty thinks Wittgenstein's thought here suggests that "any utterance can be given significance by being batted around in more or less predictable ways" [Rorty (2007), p. 172] but although Wittgenstein would have agreed that any utterance could be given a meaning, he would have been wary of the thought expressed by Rorty here. As we have already seen Wittgenstein did not think that certain words used in traditional philosophical 'theories' were given a clear sense despite being used in 'more or less predictable ways'. As Daniel Whiting notes in his introduction to a collection of essays about Wittgenstein and language, "there is a normative dimension to use...from the fact that, for example 'bachelor' means eligible, unmarried, adult male, it appears trivially to follow that it would be wrong or incorrect to apply it to a married woman or to form the sen- 
tence, 'My sister is a bachelor"' [Whiting (2010), p. 4]. If someone were to repeatedly say 'my sister is a bachelor' at ten o'clock every morning (i.e. bat the phrase about in 'more or less predictable ways') the phrase would not become any more meaningful. As in the case of traditional philosophers, if you use a word in a way that flouts the ordinary rules for its use then you need to at least explain what you mean by what you say in order to be understood.

These sharp differences between Wittgenstein's philosophy and Rorty's pragmatist philosophy tell us that whatever the virtues of Rorty's pragmatist case for liberalism it is not a case that is strongly rooted in Wittgenstein's philosophy. It might be said to be inspired by Wittgenstein's philosophy but this inspiration consists in taking words and phrases from Wittgenstein's work and twisting them beyond recognition and so Rorty's case does very little to demonstrate that there is any kind of liberalism to be found in Wittgenstein's work. In fact, given that Wittgenstein is primarily concerned with matters of grammar, sense, and nonsense, it seems clear at the very least that his concerns are not political or ideological (although his work may well be of help in dissolving conceptual confusions in the work of political philosophers, which might, indirectly lead to changes in people's ideology, perhaps by undermining the credibility of the philosopher in question).

\section{5. Crary on Rorty and Liberal Democracy}

Alice Crary, in her 'Wittgenstein's Philosophy in Relation to Political Thought' objects to Rorty's arguments in several places. She objects to the way in which he throws out the baby with the bathwater when he suggests that we should drop realist jargon (e.g. objectivity) because realism is incoherent. In this respect she is closer to Wittgenstein than Rorty, in that Wittgenstein only wanted to bring back words from their metaphysical to their ordinary use rather than drop them, as Rorty suggests. As already noted, she also objects to the way in which Rorty moves from rejecting realism to asserting something like its negative and makes a similar objection to the one that Conant has made concerning the way that Rorty just wants to discard traditional philosophy and move onto something more interesting rather than engage with the way in which philosophical problems beguile us [Crary (2000), pp. 127-129], and finally, she objects to views which attribute theses about meaning to Wittgenstein.

Rorty presents us with something like a false dichotomy, between realist philosophy and 'pure language game' philosophy. Crary notes that Wittgenstein "rejects as the product of metaphysical confusion the idea that 
we must choose between, on the one hand, having the world and forfeiting responsibility and, on the other, having responsibility and losing the world" [Crary (2000), p. 141], i.e. the kind of division that Rorty has in mind. In place of Rorty's confused 'theorising' Crary suggests that we adopt a view of Wittgenstein such that he is calling upon us to develop sensitivities acquired when mastering our language. We should, on this view, "put... to use- and perhaps stretch - our imagination" [Crary (2000) p. 140]. This seems reasonable enough. Wittgenstein's philosophy does involve us having to think about how we ordinarily use the terms that are under consideration and then to assemble to appropriate resources to tackle philosophical problems. However, it is difficult to see how Crary gets from this to the conclusion that the lessons from her interpretation of Wittgenstein's philosophy would be found "reflected in forms of social life that embody the ideals of liberal democracy" [Crary (2000), p. 141]. Crary herself says that this is only a suspicion that she has and she does not specify the ideals that she has in mind. It is also difficult to know quite what she is opposing the ideals of liberal democracy to: is she thinking about private property (liberal) vs. public property (socialist), free markets (liberal) vs. government control of industry, or perhaps maximal individual liberty vs. responsibility to a collective? Without further specification it is difficult to evaluate her conclusion and how she has arrived at it, and so I would suggest that, at best, a weak case has been made for saying that Wittgenstein's thought is reflected in the forms of social life she mentions. We might say that Wittgensteinian philosophizing is particularly encouraged by societies that allow people time to reflect, to develop their imaginative capacities, and which educate them well, but neither of these elements is tied particularly to liberal democracy. In fact, one might argue that the capitalism that has grown up with liberal democracy denies much of the world opportunities to develop in these ways. Tendencies towards specialization, and pressures to publish original material in philosophy journals in liberal democracies might also be thought to be trends that undermine philosophizing as Wittgenstein suggested.

\section{CONCLUSION}

So neither Brice, Eldridge, Rorty nor Crary has made a convincing case for there being some kind of liberal or liberal-democratic tendencies in Wittgenstein's thought. In his political pronouncements Wittgenstein himself combined elements of conservative influence with sympathy for elements of bolshevism, as well as a "Tolstoyan ideal of a life of manual 
work" [Glock (2008), p. 192]; so if there are hints of liberalism in Wittgenstein's philosophical thought it would seem that Wittgenstein himself was not particularly well attuned to them. ${ }^{37}$ Wittgenstein's political thought was not liberal and his philosophy does not obviously have any ideological implications; rather it was focused on dissolving the conceptual confusions found in the work of past philosophers. ${ }^{38}$

Instituto de Filosofia da Nova

Faculdade de Ciências Sociais e Humanas

Universidade Nova de Lisboa

Av. de Berna, $26-4^{\circ}$ Piso

1069-061 Lisboa, Portugal

E-Mail: robertvinten@gmail.com

\section{NOTES}

${ }^{1}$ See, for example, Nyiri (1976), (1982), (1986), McCauley (1976), Bloor (1983), Anderson (1969); Gellner (1959); Callinicos (1985); Janik (1985a), (1985b). Lugg, (2004); and Vinten (2013).

${ }^{2}$ It could be argued, of course, that papers arguing that Wittgenstein was a conservative philosopher indirectly answer the question of whether he was a liberal.

${ }^{3}$ Williams (2005) suggests that "the tendency of Wittgenstein's influence has been distinctly conservative" (p. 34) but thinks that a 'Left Wittgensteinianism' can be gleaned from his work (p. 37). I think Williams' arguments for these claims relies on a flawed understanding of Wittgenstein's use of the expression 'form of life'.

4 Vicente Sanfélix Vidarte has also entered into the discussion about whether Wittgenstein was a liberal. Like me, he does not think that Wittgenstein was a liberal, or that his philosophy has liberal implications, but unlike this paper he focuses on Wittgenstein's earlier philosophy [see Sanfélix (2009)].

${ }^{5}$ See, for example, Berlin (1969), p. 122.

${ }^{6}$ See, for example, Green [(1986) (1895)], p. 229.

7 See, for example, Tawney (1931), p. 221.

${ }^{8}$ In Sanfélix (2009) the author notes both that the term 'liberal' is “...far from precise" and that "though there has been...no lack of liberals who are democrats, there have been many others who were not"; p. 119 and p. 120 respectively.

${ }^{9}$ Courtland, Gaus and Schmidtz (1996). Note: Ryan (1993), says that, “....it would be absurd to call Hobbes a liberal even while one might want to acknowledge that he supplied many of the ingredients for a liberal theory of politics" [Ryan (1993), p. 298].

${ }^{10}$ Soifer and Szabados (2004), p. 214, explain why Locke took these stances: "Locke believed that Catholics, through their acceptance of the authority of the 
Pope, had in effect declared allegiance to another sovereign and thus could not be tolerated within civil society. Similarly, he believed that the oaths and pledges of atheists could not be relied upon, since they had no divine sanction to back them up".

11 All of the references above to the El Mercurio article refer to 'Extracts from an Interview with Friedrich von Hayek', El Mercurio, Santiago de Chile, 12th April 1981, pp. D8-D9. The text of the interviews with Hayek can be found in Caldwell and Montes (2015), pp. 261-309.

12 Interestingly, even Tony Blair and Jack Straw, of Britain's Labour Party helped Pinochet to avoid being brought to justice (see 'Secret UK deal freed Pinochet', the Guardian, $7^{\text {th }}$ January 2001, < http:/ /www.theguardian. com/world/2001/ jan/07/chile.pinochet $>$ ) (accessed 19/01/16).

${ }_{13}$ Brice cites Rawls here, with regard to the use of the expression 'reasonable pluralism' [Rawls (2005), p. 4].

14 In Rorty (1999), p. 207, he says that, "[t] he rise of the trade unions is, morally speaking, the most encouraging development of modern times". (The article first appeared as 'Endlich sieht man Freudenthal' in Frankfurter Allgemeine Zeitung, 20 ${ }^{\text {th }}$ February 1998).

${ }^{15}$ See, for example, 'Trotsky and the Wild Orchids' where Rorty says that "welfare state capitalism is the best we can hope for" [Rorty (1999), p. 17] and 'Looking Backwards from the Year 2096' where Rorty suggests that "fully fledged welfare states" will promote economic development and defend against civil unrest [Ibid., p. 247-250].

16 Also see 'Looking Backwards from the Year 2096' where he says that "a viable economy requires free markets" [Rorty (1999) p. 244].

17 So, for example, in 'Hilary Putnam and the Relativist Menace' he says that '[c]riticism of other philosophers' distinctions and problematics should charge relative inutility rather than 'meaninglessness' or 'illusion' or 'incoherence", in Rorty (1998) p. 45.

${ }^{18}$ In 'A World without Substances or Essences' Rorty says that we should see language "as providing tools for coping with objects rather than representations of objects, and as providing tools for different purposes", in Rorty (1999), p. 65.

${ }^{19}$ For example, he talks approvingly of Dewey hoping that "we would stop using the juridical vocabulary which Kant made fashionable among philosophers, and start using metaphors drawn from town meetings rather than tribunals" [Rorty (1999), p. 111].

${ }^{20}$ Wittgenstein continues to use the comparison with tools throughout the Philosophical Investigations - see, for example, $₫ 14, \$ 15, \$ 17, \S 23, \S 53, \S 360$.

${ }^{21} \mathrm{It}$ is worth briefly noting here that Wittgenstein never actually employed the slogan used by Rorty. It was first offered up by John Wisdom as epitomising Wittgenstein's view [Wisdom (1953), p. 117].

22 So, for example, he quotes Sabina Lovibond approvingly when she says that, "[a]n adherent of Wittgenstein's view of language should equate that goal with the establishment of a language game in which we could participate ingenu- 
ously, while retaining our awareness of it as a specific historical formation. A community in which such a language game was played would be one... whose members understood their own form of life and yet were not embarrassed by it" [quoted in Rorty (1991), p. 32, fn. 15] [the passage is originally from Lovibond, (1983), p. 158] and presumably he thinks that Lovibond's talk of establishing a language game parallels his own talk of shifting vocabularies.

23 Wittgenstein (1984), 17e - where Wittgenstein says, "Ramsey was a bourgeois thinker, i.e. he thought with the aim of clearing up the affairs of some particular community. He did not reflect on the essence of the state - or at least he did not like doing so - but on how this state might reasonably be organized. The idea that this state might not be the only possible one partly disquieted him and partly bored him. He wanted to get down as quickly as possible to reflecting on the foundations - of this state".

${ }^{24}$ In a letter to Norman Malcolm, written shortly after the end of the Second World War, Wittgenstein said that, “[p]erhaps I ought to feel elated because the war is over. But I'm not. I can't help feeling certain that this peace is only a truce. And the pretence that the complete stamping out of the 'aggressors' of this war will make this world a better place to live in, as a future war could, of course, only be started by them, stinks to high heaven $\&$, in fact, promises a horrid future" [Malcolm (2001), p. 97].

${ }^{25}$ Wittgenstein, L. 'Remarks on Frazer's “Golden Bough”, cited in Hacker (2001), p. 82.

26 Brice (2014) p. 92. Brice cites OC \$256 (“...the language game does change with time"), $\$ 559$ ("You must bear in mind that the language game is so to say something unpredictable. I mean: it is not based on grounds. It is not reasonable (or unreasonable). It is there-like our life.") and $\$ 97$ ("The mythology may change back into a state of flux, the river-bed of thoughts may shift. But I distinguish between the movement of the waters on the river-bed and the shift of the bed itself; though there is not a sharp division of one from the other").

27 And, as mentioned earlier, this was not Brice's intention. He says that, “...it was not my purpose to argue that one social/political interpretation of Wittgenstein is right, or better than another. Indeed, drawing conclusions about Wittgenstein's political temperament by pointing to passages that seem to confirm a particular position, while simultaneously overlooking other passages that may contradict that position, is most certainly wrong... Rather, my purpose was to show the distractive power... such 'arguments' have on us" [Brice (2014), p. 93].

${ }^{28}$ Ray Monk picks up on hints of perfectionism in Wittgenstein's work in the subtitle to his biography of Wittgenstein - 'The Duty of Genius' (thanks to an anonymous referee for this point).

29 See Glock (1991): for an excellent discussion of what Wittgenstein means by 'theses' in this context.

30 Wittgenstein (1993a), pp. 161-163, 171. Cited on p. 109 of Eldridge (1997).

${ }^{31}$ Cited in Eldridge (1997), p. 109.

32 Wittgenstein (2009), \$131. 
33 Eldridge is amongst those interpreters of Wittgenstein who take the Philosophical Investigations to be a literary text and so puts pressure on the philosophy/literature distinction. Eldridge wants to suggest that the 'voices' in the text are in a discussion that never comes to resolution, in contrast to, for example, Peter Hacker, who want to suggest that Wittgenstein presents conclusive arguments against certain philosophical positions (including Wittgenstein's own earlier views). See, for example, Hacker (2003).

34 Wittgenstein (1993a), \$119. Elsewhere Wittgenstein says: “To say that this proposition ['This is how things are'] agrees (or does not agree) with reality would be obvious nonsense” (\$134) and “... only I can know whether I am really in pain: another person can only surmise it. - In one way this is wrong, and in another nonsense..." (\$246). (See also \$252, \$282, \464, \524).

35 See also, Putnam (1995), pp. 27-56 for a full discussion of why Putnam thinks that it is mistaken to describe Wittgenstein as a pragmatist.

36 See, for example, Wittgenstein's Blue Book, where he examines the grammar of the relevant terms involved in disputes between idealists, solipsists, and realists [Wittgenstein (1958), pp. 48-49].

${ }^{37}$ For a good overview of Wittgenstein's various political opinions see Ray Monk's autobiography of Wittgenstein - Monk (1990).

${ }^{38}$ I would like to thank the FCT for funding my research work at Universidade Nova de Lisboa. I would also like to thank Vicente Sanfélix Vidarte for inviting me to the University of Valencia to present my work there as well as the participants in the seminar where I presented this paper - particularly Nicolás Sánchez Durá. I'm grateful to Simon Glendinning, Nuno Venturinha and two anonymous referees of teorema for their comments on this paper. Finally, I would like to thank Carlota Dolores Sánchez García for translating my paper before the seminar at the University of Valencia.

\section{REFERENCES}

ANDERSON, P. (1969), 'Components of the National Culture', in R. Blackburn \& A. Cockburn (eds.) Student Power: Problems, Diagnosis, Action, London, Penguin Books.

ArmitAge, D. (2004), John Locke, Carolina, and the "Two Treatises of Government", Political Theory, Vol. 32, No. 5.

BAKER, G. P. and HACKER, P. M. S. (2009), Wittgenstein: Rules, Grammar and Necessity, (second edition, extensively revised by P. M. S. Hacker), Oxford, Wiley-Blackwell.

Berlin, I. (1969), 'Two Concepts of Liberty' in Four Essays on Liberty, Oxford, Oxford University Press.

BLOOR, D. (1983), Wittgenstein: A Social Theory of Knowledge, New York, Macmillan.

BRICE, R. G. (2014), Exploring Certainty: Wittgenstein and Wide Fields of Thought, Lanham, Lexington Books. 
Caldwell, B. and Montes, L. (2015), 'Friedrich Hayek and his visits to Chile', The Review of Austrian Economics, 28 (3), pp. 261-309.

Caldinicos, A. (1985), Marxism and Philosophy, Oxford, Oxford University Press.

Conant, J. (1990), 'Introduction' to Putnam, H. Realism with a Human Face, Cambridge, Harvard University Press.

Courtland, D., GAus, G., and SCHMIDTZ, D. (1996), 'Liberalism', in Stanford Encyclopedia of Philosophy, <http://plato.stanford. edu/entries/liberalism/> (first published in 1996, revised in 2014).

Crary, A. (2000), 'Wittgenstein's Philosophy in Relation to Political Thought', in Crary, A. and Read, R., The New Wittgenstein, London, Routledge.

- (2003), 'Wittgenstein's Pragmatic Strain' in Social Research, Summer, 70, 2.

ELDRIDGE, R. (1997), Leading a Human Life: Wittgenstein, Intentionality, and Romanticism, Chicago, The University of Chicago Press.

- (2003), 'Wittgenstein and the Conversation of Justice' in Cressida Heyes (ed.), The Grammar of Politics, Ithaca, Cornell University Press.

GeLLnER, E. (1959), Words and Things: An Examination of, and an Attack on, Linguistic Philosophy, Victor Gollancz Ltd.

GLOCK, H-J. (1991), 'Philosophical Investigations section 128: Theses in philosophy and undogmatic procedure'; in Glock, H.-J. and Arrington, R., Wittgenstein's Philosophical Investigations, London/New York, Routledge

- (2008), What is Analytic Philosophy?, Cambridge, Cambridge University Press.

GreEn, T. H. [1986 (1895)], Lectures on the Principles of Political Obligation and Other Essays, Paul Harris and John Morrow (eds.) Cambridge, Cambridge University Press.

HACKER, P. M. S. (2001), 'Wittgenstein on Frazer's Golden Bough', in Hacker, P. M. S., Wittgenstein: Connections and Controversies, Oxford, Oxford University Press.

- (2007), 'Gordon Baker's Late Interpretation of Wittgenstein' in G. Kahane, E. Kanterian, and O. Kuusela (eds.) Interpretations of Wittgenstein, Blackwell, Oxford.

Heyes, C. (2003) (ed.), The Grammar of Politics, Ithaca, Cornell University Press.

JANIK, A. (1985a), 'Nyíri on the Conservatism of Wittgenstein's Later Philosophy', in Allan Janik's Essays on Wittgenstein and Weininger, Amsterdam, Rodopi.

- (1985b), 'Wittgenstein, Marx and Sociology' in Allan Janik's Essays on Wittgenstein and Weininger, Amsterdam, Rodopi.

Kitching, G. and Pleasants, N. (2002), Marx and Wittgenstein: Knowledge, Morality and Politics, London, Routledge.

LANDAU, S. (2003), 'The Chilean Coup', Counterpunch, September 11th 2003.

LOVIBOND, S. (1983), Realism and Imagination in Ethics, Minneapolis, University of Minnesota Press.

LugG, A. (2004), 'Wittgenstein and Politics: Not Right, Left or Center', International Studies in Philosophy, 36:1, pp. 61-79.

Malcolm, N. (2001), Ludwig Wittgenstein: A Memoir, (2nd edition) Oxford, Clarendon Press. 
Mccauley, H. C. (1976), 'Wittgenstein: Philosophy and Political Thought', The Maynooth Review, 2:2, pp. 13-26.

MiLL, J. S. (1869), On Liberty, London, Longman, Roberts, \& Green co.

MonK, R. (1990), Ludwig Wittgenstein: The Duty of Genius, New York, Penguin.

NyIRI, J. C. (1976), 'Wittgenstein's New Traditionalism', Acta Philosofica Fennica, Vol. 27, pp. 503-509.

- (1982), 'Wittgenstein's Later Work in Relation to Conservatism'; in Anthony Kenny \& Brian McGuinness (eds.) Wittgenstein and His Times, Chicago, University of Chicago Press.

- (1986), 'Wittgenstein 1929-31: The Turning Back' [in Stuart Shanker (ed.) Ludwig Wittgenstein: Critical Assessments (Vol. 4), London, Routledge, pp. 29-59].

Putnam, H. (1995), Pragmatism, Oxford, Blackwell.

RAwls, J. (2005), Political Liberalism, New York, Columbia University Press.

Rorty, R. (1989), Contingency, Irony, and Solidarity, Cambridge, Cambridge University Press.

- (1990), 'Priority of Democracy to Philosophy', in Alan Malachowski (ed.), Reading Rorty, Oxford, Blackwell, p. 285.

- (1991), Objectivity, Relativism and Truth, Philosophical Papers, Volume 1, Cambridge, Cambridge University Press.

- (1998), 'Hilary Putnam and the Relativist Menace' in Truth and Progress: Philosophical Papers, Vol. 3., Cambridge, Cambridge University Press.

- (1999), Philosophy and Social Hope, London, Penguin Books.

- (2007), 'Wittgenstein and the linguistic turn', in Philosophy as Cultural Politics, Vol. 4 Philosophical Papers, Cambridge, Cambridge University Press.

Ryan, A. (1993), 'Liberalism', in A Companion to Contemporary Political Philosophy, Oxford, Blackwell, pp. 291-311.

SANFÉLIX VIDARTE, V. (2009), 'Was Wittgenstein a Liberal?' in K. Wojchiechowski and J. Joerden (eds.), Ethical Liberalism in Contemporary Societies, Peter Lang.

SCHulte, J. (1986), 'Wittgenstein and Conservatism' in Stuart Shanker (ed.) Ludwig Wittgenstein:Critical Assessments, Vol. 4, London, Routledge, pp. 60-69.

SoIfer, E. and SzABADOS, B. (2004), Hypocrisy: Ethical Investigations, Toronto, Broadview Press.

TAWNEY, R. H. (1931), Equality, New York, Harcourt Brace.

THOMAs, D. L. (1995), Routledge Pbilosophy Guidebook to Locke on Government, London, Routledge.

Thomson, G. (1979), 'Wittgenstein: Some Personal Recollections', Revolutionary World, XXXVII, no. 9, pp. 87-88.

VINTEN, R. (2013), 'Leave Everything as it is: A Critique of Marxist Interpretations of Wittgenstein', Critique, Vol. 41, Issue 1, pp. 9-22.

Whiting, D. (2010), 'Introduction' in Whiting, D. (ed.) The Later Wittgenstein on Language, Basingstoke, Palgrave Macmillan.

Williams, B. (2005), 'Pluralism, Community and Left Wittgensteinianism', in B. Williams, In the Beginning was the Deed: Realism and Moralism in Political Argument, Princeton NJ, Princeton University Press. 
WisDom, J. (1953), Philosophy and Psycho-analysis, Oxford, Oxford University Press.

WiTTGENSTEIN, L. (1939), L. Wittgenstein's Lectures on the Foundations of Mathematics, ed. C. Diamond (1976), Harvester, Hassocks, Sussex.

- (1958), The Blue and Brown Books, New York, Harper \& Row.

- (1961), Tractatus Logico-Philosophicus, London, Routledge.

- (1967), Zettel, ed. G. E. M. Anscombe and G. H. von Wright, tr. G. E. M. Anscombe, Oxford, Blackwell.

- (1974), Philosophical Grammar, ed. R. Rhees, trans. A. J. P. Kenny, Oxford, Blackwell.

- (1980), Culture and Value, ed. G. H. von Wright in collaboration with Heikki Nyman, Oxford, Blackwell.

- (1993a), 'Philosophy: Sections 86-93 called the "Big Typescript" (Catalogue Number 213)', in Philosophical Occasions 1912-1951, ed. J. Klagge and A. Nordmann, Indianapolis, Hackett.

- (1993b), 'Remarks on Frazer's Golden Bough', in Philosophical Occasions, Cambridge, Hackett Publishing Company.

- (2005), The Big Typescript. TS 213, Grant Luckhardt and Maximilian Aue (eds. and trans.), Oxford, Wiley-Blackwell.

- (2009), Philosophical Investigations, trans. G. E. M. Anscombe, P. M. S. Hacker and J. Schulte (Revised 4th edition by P. M. S. Hacker and J. Schulte), Oxford, Wiley-Blackwell. 